msh-mss Mathématiques et sciences humaines

139 | Automne 1997

Varia

\title{
Structures grammaticales dans le français mathématique : 2 (suite et fin)
}

Grammatical structure in mathematical french language: 2 (end)

Aarne Ranta

\section{(2) OpenEdition}

\section{Journals}

Édition électronique

URL : http://journals.openedition.org/msh/2772

DOI : $10.4000 / \mathrm{msh} .2772$

ISSN : 1950-6821

Éditeur

Centre d'analyse et de mathématique sociales de l'EHESS

Édition imprimée

Date de publication : 1 septembre 1997

ISSN : 0987-6936

Référence électronique

Aarne Ranta, «Structures grammaticales dans le français mathématique : 2 (suite et fin) »,

Mathématiques et sciences humaines [En ligne], 139 | Automne 1997, mis en ligne le 10 février 2006,

consulté le 23 juillet 2020. URL : http://journals.openedition.org/msh/2772 ; DOI : https://doi.org/

$10.4000 / m s h .2772$

(c) École des hautes études en sciences sociales 
Math. Inf. Sci. hum., (35 ${ }^{\mathrm{e}}$ année, ${ }^{\circ} 139,1997$, pp. 5-36)

\title{
STRUCTURES GRAMMATICALES DANS LE FRANÇAIS MATHÉMATIQUE : II - (suite et fin) ${ }^{1}$
}

\begin{abstract}
Aarne RANTA ${ }^{2}$
RÉSUMÉ - Un système de règles grammaticales est présenté pour analyser un fragment du français permettant l'expression de théorèmes et de preuves mathématiques. Pour cet objectif, on développe une version de la grammaire de Montague, avec des catégories syntaxiques relatives au contexte et aux domaines d'individus. Ce système peut être interprété dans la théorie constructive des types de Martin-Löf. Il est appliqué, d'abord, au français sans symboles mathématiques, avec une attention spéciale aux restrictions de sélection et aux dépendances par rapport à un contexte. Le fragment comprend des verbes et des adjectifs, des formes plurielles, des propositions relatives, et des syntagmes coordonnés. Ensuite, la grammaire est étendue au symbolisme mathématique et à son usage dans le texte français. Le fragment comprend des formules arithmétiques, la notation décimale, les conventions de parenthèses, les variables explicites, des énoncés de théorèmes et des structures textuelles de preuves. On finit par étudier quelques applications de la grammaire, basées sur l'implémentation déclarative de la grammaire dans $A L F$, un éditeur de preuves.
\end{abstract}

SUMMARY - Grammatical Structure in Mathematical French: II.

A system of grammatical rules is presented to analyse a fragment of French that permits the expression of mathematical theorems and proofs. To this end, a version of Montague grammar is developed, with syntactic categories relativized to a context and to domains of individuals. This system can be interpreted in the constructive type theory of Martin-Löf. It is first applied to French without mathematical symbols, paying special attention to selectional restrictions and to dependencies on context. The fragment includes verbs and adjectives, plurals, relative clauses, and coordinated phrases of different categories. Second, the grammar is extended to mathematical symbolism and its embedding in French text. The fragment comprises arithmetical formulae, decimal notation, parenthesis conventions, explicit variables, statements of theorems, and textual structures of proofs. Finally, some applications of the grammar are studied, based on a declarative implementation in the proof editor ALF.

\footnotetext{
${ }^{1}$ La première partie de cet article a paru dans le $n^{\circ} 138$ de cette revue, pages 5 à 56 , sous le titre «Structures grammaticales dans le français mathématique : I».

${ }_{2}^{2}$ Département de Philosophie, B.P. 24, 00014 Université d'Helsinki, Finlande.

Cet article est une synthèse du travail dont j'ai eu l'occasion de présenter des extraits à Paris et à Nancy en février 1996. Je suis reconnaissant aux publics de ces conférences pour leurs remarques et, en particulier, à M. Bourdeau et J.-P. Desclés, de l'Université de Paris-Sorbonne, à D. Lacombe, de l'Université de Paris VII, et à C. Retoré, de l'INRIA Lorraine, pour les entretiens privés sur les thèmes de l'article. P. Martin-Löf, de l'Université de Stockholm, m'a aidé pendant tout le travail par ses critiques et conseils. U. Egli, de l'Université de Constance, A. Lecomte, de l'Université de Grenoble et P. Mäenpää, de l'Université d'Helsinki ont lu la première version de l'article et fait des remarques pertinentes sur le contenu. En outre, M. Bourdeau et A. Lecomte ont corrigé le français des versions préliminaires. Les fautes qui restent dans la version finale sont miennes.
} 
